\title{
An Systematic Research Analogy on Human Resource (HR) Policies and its Implementation at BPO in India
}

\author{
Sagarika Bose*(MBA $1^{\text {st }}$ Year, NSHM Knowledge Campus, Durgapur)
}

\begin{abstract}
Assistant Prof. Amrita Bhattacharya (Department Of Management Studies, NSHM Knowledge Campus, Durgapur)
\end{abstract}

\begin{abstract}
The industry has been growing rapidly. At the present time, when the business scenario is completely ruthless due to the impending pandemic it is very hard to keep hold of the knowledge based in professional BPO industries. The BPO Industries have high friction or employee turnover rate which not only have side effects which includes decreased productivity, increased recruitment costs, avoidable time spent on training new employees, and lost sales but also businesses with high staff turnover typically experience low employee morale and productivity rates. Hence the involvement of HR policies plays a crucial role in retaining, identifying, motivating the right spirited employees and ensuring that the employees are aware of their rights and they feel safe and encouraged within the business environment. As per the findings of this paper the major problems arising in BPO sector is that employees do not know about the HR policies, they believe in positive reinforcement only and that the employees and HR professional do not see an impact of the HR policies on performance of the company as a whole. This HR Policies related study is to pave the way of BPO companies to change their views and ideologies regarding the company employees and treat them as an investment giving them their required priority.
\end{abstract}

Keywords: HR Policies, BPO, Attrition

\section{INTRODUCTION:}

1.1 Background of the Study: Human Resource policies are official rules and guidelines that businesses work along with in order to manage their employees and so thus the working environment. HR strategy, in contrast, is one step at a time instructions that signifies what measures should be taken to get along with these policies. Thus, as a matter of fact, these policies provide recommendation for a wide category of employment correspondence within the organization. The motive and importance of the HR policies hardly need any elaboration. Every working corporation requisite policies that ensures consistency in action and egalitarianism in its correspondence with employees. HR procedures often take the form of Standard Operating Procedure (SOP) documents. Human Resource Management (HRM) such as recruitment, promotion, compensation, training, selections etc. Thus they serve as a testimonial point when HR management operations are being procedurized or when decisions are being formularized about an organization's livewire. An acceptable HR policy lays out generalized enlightenment on the various approaches embraced by the organization, and so thus its employees, concerning various stages of employment. The Strategy spells out precisely whatever actions that should be taken in line along with the policies. Efficient HR practices do indeed make a difference in term of business effectiveness. Efficient HR practices are considered as those that contribute to one or more of the three $\mathrm{C}^{\mathrm{ce}} \mathrm{s}$ : one is Competencies, the second one is Commitment and the last one is Culture. They need to be signified and acknowledged costeffectively, evaluating and exploring them from time again to enhance their productiveness and successfulness. HR Practices include: HR Planning, Recruitment \& Selection, and Activities beyond Statutory Requirement, Safety, Health and Environment Policy, Suggestions Scheme, Promotion \& Transfers, Exit Policy. BPO is the abbreviation for Business Process Outsourcing, which refers to when companies outsource business processes to a third-party (external) company. The primary goal is to cut 
* They are a like set of prescriptions for superintendent and managers for carrying out their behaviour with corresponding employees working within the organization.

* They provide a basis for evolving the employee handbook.

* They establish a kernel for consecutively reviewing possible changes influencing employees.

* They create a context for superintendent training programs and employee training orientation programs.

2.3 Specifications: HR Policies should always follow certain specified rules in order to be applicable-

* HR policies should always have the primary objective of contributing to organisational objectives.

* HR policy should create awareness among the employees of their significance and position within the organisation.

* A HR policy should always be in writing.

\subsection{Business Process Outsourcing (BPO):}

Business Process Outsourcing (BPO), is basically a kind of outsourcing in which the company subcontracts specific business processes to a third party service provider who can accomplish or carry out those processes on the customer's behalf at a certain cost. These activities could include document processing, payroll, technical support, HR, marketing, etc. BPO permits a company to save cost and also focus on the core activities.

2.4.1.1 BPO Services in India: Look Over: There was an unanticipated resonance in the outsourcing sector in India from 2004-2005, not just within the domestic market but also in the export market of BPO where foreign clients were off-shoring their back office and procedural functions to Indian BPOs due to the advantage of cost and work quality they are offered. The major factors of such increasing growth are costworthy telecommunications and easy inherence of English communicating workforce with monumental technicalities know-how in India. The foremost customers who are mainly make the most from the BPO services are the industries related to Pharmaceuticals, Insurance, Telecom, Healthcare, Automotive, Banking and Finance, E-commerce and Retail, and Airlines. Some of the leading BPO organizations, well known for their performance and service standards in India are Accenture, Tata Consultancy Services, Hewlett Packard, Infosys BPO, HCL, IBM-Daksh, Cap Gemini, Convergys, and Wipro to name a few. In a nutshell, the main reasons for the growth of business process outsourcing services in India are:

\# Cost Factor Advantage
\# Utilization Improvement
\# Decreasing trade barriers

* Superior Competency

* Economy of Scale

* Business Risk

Mitigation

\subsection{Intention:}

* To identify the various Human Resource Policies that is being acknowledged by various industries.

* To distinguish the numerous accomplishment of the HR polices on Business Process Outsourcing (BPO).

* 2.5.1 Extent of the Research:

* Creates a viewpoint towards the HR Professionals working under various BPO Sectors. 
* This study is to magnifies the belief that the HR practices are efficient and capable enough.

* This study calls attention to the significance of the existence of the HR policies and their implementation in BPO Industry.

* This study makes a way for future research and serves as source for future reference.

3. RESEARCH METHODOLOGY: The current study overviews the various Human Resource Policies and their implementation at BPO's.

Strength of the Sample - 150

Acquired Research Data - Primary and Secondary Methods

Tools of Research - Sampling

Statistical Tools-

Percentage,

Chi-Square

Test,

Rank

Correlation

\subsection{Data Analysis:}

Table1. Grasping tendency of the HR Policies among HR Professionals

\begin{tabular}{|c|c|c|c|}
\hline S.No & Element & Density & $\%$ \\
\hline 1 & Yes & 60 & 22 \\
\hline 2 & No & 90 & 78 \\
\hline & Total & 150 & 100 \\
\hline
\end{tabular}

Conclusion: $78 \%$ of HR professionals are unaware about HRA and only $30 \%$ of the respondents are aware of the HRA.

Table2. Impact of HR Policies in Decision Making

\begin{tabular}{|r|r|r|r|}
\hline S.No & \multicolumn{1}{|c|}{ Element } & Density & $\%$ \\
\hline 1 Knowledge Regarding Organizational Policies & 32 & 24 \\
\hline 2 HR Associated Updates & 45 & 26 \\
\hline 3 Hiring of Personnel & 26 & 17 \\
\hline 4 Performance Evaluation of the Employee & 47 & 33 \\
\hline Total & 150 & 100 \\
\hline
\end{tabular}

Conclusion: $33 \%$ of the HR's realizes the effects of the Performance Evaluation of the Employee and 26\% of them realizes about the HR related updates. $24 \%$ and $17 \%$ of them feel its related to the organisational policies knowledge and appointment of the employees. 
Table3. Essential HR Policies

\begin{tabular}{|c|c|c|c|}
\hline S.No & Element & Density & $\%$ \\
\hline 1 & Recruitment Policy & 39 & 28 \\
\hline 2 & Anti-Harassment and Non-Discrimination Policy & 16 & 12 \\
\hline 3 & Rewards \& Recognition & 24 & 9 \\
\hline 4 & Career Planning & 12 & 19 \\
\hline 5 & Leave and Time-Off Benefits Policy & 15 & 8 \\
\hline 6 & Compensation \& Benefits & 10 & 4 \\
\hline 7 & Timekeeping and Pay Policy & 13 & 6 \\
\hline 8 & Employee Conduct, Attendance \& Punctuality Policy & 21 & 14 \\
\hline & Total & 150 & 100 \\
\hline
\end{tabular}

Conclusion: $28 \%$ and 19\% of the respondents feel that Recruit Policy and Reward \& Recognition are the best practices in the company. $14 \%$ and $12 \%$ of the respondents feel that Employee Conduct and Anti-Harassment \& Non-Discrimination Policy are the best. $9 \%, 8 \%, 6 \% \& 4 \%$ of the respondents are of the opinion that Career Planning, Benefit Policies, Pay Policy and Benefits are the best practices.

\section{Table4. Threats prone to HR Personnel at BPO}

\begin{tabular}{|c|c|c|c|}
\hline S.No & Elements & Density & $\%$ \\
\hline 1 & Changing Political Scenarios & 23 & 15 \\
\hline 2 & Exceeding Customer Expectations & 13 & 8 \\
\hline 3 & Shoestring Budgets & 25 & 19 \\
\hline 4 & Health Concers & 16 & 11 \\
\hline 5 & Customer Attrition & 15 & 9 \\
\hline 6 & Scarcity of Talent & 11 & 7 \\
\hline 7 & Employee Attrition & 29 & 21 \\
\hline 8 & Communication Channels & 18 & 10 \\
\hline & Total & 150 & 100 \\
\hline
\end{tabular}

Conclusion: $21 \%$ \& 19\% of the respondents feel that Employee Attrition and Shoestring Budgets are the threats faced highly by the BPO. $15 \%$ \& $11 \%$ of the respondents feel that it poses a threat due to Changing Political Scenarios and Health Concerns. $10 \%, 9 \%, 8 \%$ \& $7 \%$ of the respondents poses a threat because of Communication Channels, Customer Attrition, Exceeding Customer Expectations and Scarcity of talent.

\subsection{Chi Square Inspection:}

A comparison between Respective Age and Conscious Awareness of HR Policies at HR BPO:

\begin{tabular}{|l|l|l|l|l|}
\hline \multirow{2}{*}{ S.No } & \multirow{2}{*}{ Respective Age } & \multicolumn{3}{|c|}{ Respective Cognizance Among HR Professionals } \\
\cline { 3 - 5 } & & Yes & No & Total \\
\hline 1 & $25-30$ & 15 & 5 & 20 \\
\hline 2 & $30-35$ & 14 & 7 & 21 \\
\hline 3 & $35-45$ & 3 & 11 & 14 \\
\hline 4 & $45-50$ & 2 & 40 & 42 \\
\hline 5 & $>50$ & 1 & 52 & 53 \\
\hline 6 & Total & 35 & 115 & 150 \\
\hline
\end{tabular}




\begin{tabular}{|l|l|l|l|}
\hline R5 & R8 & D= R5-R8 & D $^{2}$ \\
\hline 5 & 2 & \multicolumn{2}{|l|}{9} \\
\hline 8 & 3 & 5 & 25 \\
\hline 2 & 8 & -6 & 36 \\
\hline 1 & 7 & -6 & 36 \\
\hline
\end{tabular}

\section{Calculations:-}

\begin{tabular}{|c|c|c|c|c|c|}
\hline S.No & Observed Frequency $(\mathbf{O})$ & Expected Frequency $(\mathbf{E})$ & $(\mathbf{O}-\mathbf{E})$ & $(\mathbf{O - E - 0 . 5})^{\wedge} \mathbf{2}$ & $\left.(\mathbf{( O - E - \mathbf { O . 5 } )})^{\wedge} \mathbf{2}\right) \mathbf{E}$ \\
\hline 1 & 15 & 0.133333 & 14.866667 & 206.4011 & 1548.0121 \\
\hline 2 & 14 & 0.14 & 13.86 & 178.4896 & 1274.9257 \\
\hline 3 & 3 & 0.093333 & 2.906667 & 5.79205 & 62.0579 \\
\hline 4 & 2 & 0.28 & 1.72 & 1.4884 & 5.3157 \\
\hline 5 & 1 & 0.353333 & 0.646667 & 0.0215 & 0.0608 \\
\hline 6 & 5 & 6.933333 & -1.933333 & 5.9211 & 0.8541 \\
\hline 7 & 7 & 7.28 & -0.28 & 0.6084 & 0.0836 \\
\hline 8 & 11 & 4.853333 & 6.146667 & 31.8848 & 6.5697 \\
\hline 9 & 40 & 14.56 & 25.44 & 622.0036 & 42.72 \\
\hline 10 & 52 & 18.373333 & 33.626667 & 1097.3761 & 59.7266 \\
\hline & & & & & $\Sigma=3000.3262$ \\
\hline
\end{tabular}

The Calculated Value $=3000.3262$

Degrees Of Freedom $(\mathrm{df})=(\mathrm{r}-1) *(\mathrm{c}-1)$

$$
=(5-1) *(2-1) \text {. }
$$

\section{Conclusion:}

The Indexed Value of Chi-Square $\alpha=0.05$ for 4 df is 9.488 .

Since the calculated value is $>$ table value,

$\mathrm{H}_{1}=$ Accepted

$\mathrm{H}_{0}=$ Rejected

There is a remarkable difference between the Age of HR at BPO and their Cognizance of the HR

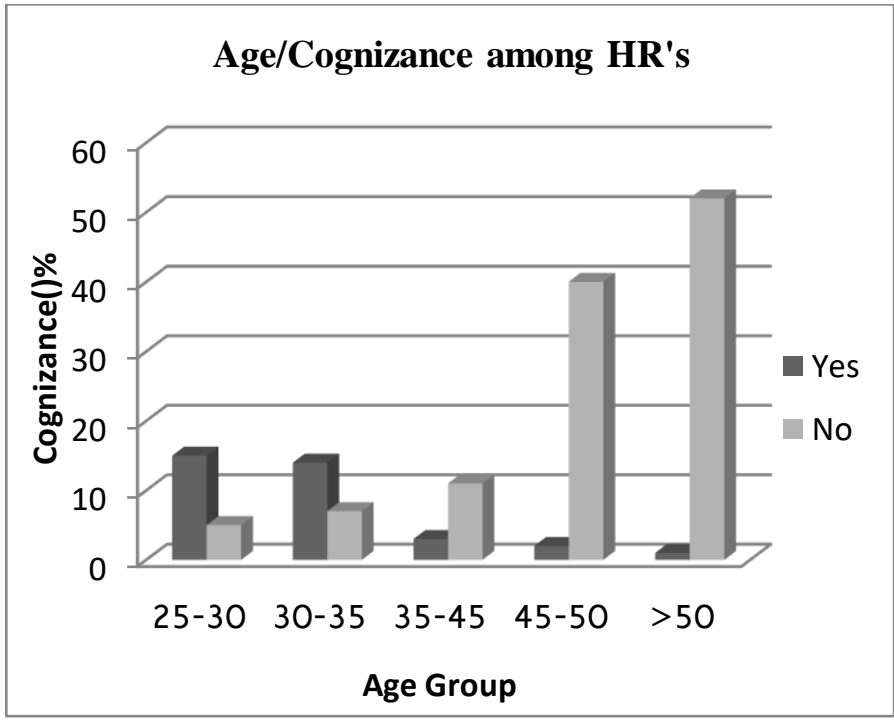
Policies. 


\begin{tabular}{|c|c|c|c|}
\hline 6 & 5 & 1 & 1 \\
\hline 3 & 4 & -1 & 1 \\
\hline 7 & 1 & 6 & 36 \\
\hline \multirow[t]{2}{*}{4} & 6 & -2 & 4 \\
\hline & & & $\sum \mathrm{D}^{2}=148$ \\
\hline R5 & R8 & $\mathrm{D}=\mathrm{R5}-\mathrm{R8}$ & $\mathrm{D}^{2}$ \\
\hline 5 & 2 & 3 & 9 \\
\hline 8 & 3 & 5 & 25 \\
\hline 2 & 8 & -6 & 36 \\
\hline 1 & 7 & -6 & 36 \\
\hline 6 & 5 & 1 & 1 \\
\hline 3 & 4 & -1 & 1 \\
\hline 7 & 1 & 6 & 36 \\
\hline \multirow[t]{2}{*}{4} & 6 & -2 & 4 \\
\hline & & & $\sum \mathrm{D}^{2}=148$ \\
\hline R5 & R8 & $\mathrm{D}=\mathrm{R5}-\mathrm{R8}$ & $\mathrm{D}^{2}$ \\
\hline 5 & 2 & 3 & 9 \\
\hline 8 & 3 & 5 & 25 \\
\hline 2 & 8 & -6 & 36 \\
\hline 1 & 7 & -6 & 36 \\
\hline 6 & 5 & 1 & 1 \\
\hline 3 & 4 & -1 & 1 \\
\hline 7 & 1 & 6 & 36 \\
\hline \multirow[t]{2}{*}{4} & 6 & -2 & 4 \\
\hline & & & $\sum \mathrm{D}^{2}=148$ \\
\hline
\end{tabular}

3.3 Spearman's Rank Correlation Co-efficient: A juxtaposition between Enlistment and Total Employee Experience towards best HR practices in the company:

Rank Correlation between Leave and Time-Off Benefits Policy \& Employee Conduct, Attendance and Punctuality Policy.

Null Hypothesis $\left(\mathbf{H}_{\mathbf{0}}\right)$ : There is no correlation between the factors of Leave and Time-Off Benefits Policy \& Employee Conduct, Attendance and Punctuality Policy.

Alternative Hypothesis: There is a correlation between the factors of Leave and Time-Off Benefits Policy \& Employee Conduct, Attendance and Punctuality Policy. 


\begin{tabular}{|c|c|c|c|c|c|c|c|c|c|c|}
\hline & Elements & Rank 1 & Rank 2 & Rank 3 & Rank 4 & $\begin{array}{l}\text { Rank } \\
5\end{array}$ & Rank 6 & Rank 7 & Rank 8 & \\
\hline \multirow[t]{19}{*}{ S.No } & & $\begin{array}{l}\text { No. of } \\
\text { Respond } \\
\text { ent }\end{array}$ & $\begin{array}{l}\text { No. of } \\
\text { Respond } \\
\text { ent }\end{array}$ & $\begin{array}{l}\text { No. of } \\
\text { Respond } \\
\text { ent }\end{array}$ & $\begin{array}{l}\text { No. of } \\
\text { Respon } \\
\text { dent }\end{array}$ & $\begin{array}{l}\text { No. of } \\
\text { Respon } \\
\text { dent }\end{array}$ & $\begin{array}{l}\text { No. of } \\
\text { Respon } \\
\text { dent }\end{array}$ & $\begin{array}{l}\text { No. of } \\
\text { Respon } \\
\text { dent }\end{array}$ & $\begin{array}{l}\text { No. of } \\
\text { Respon } \\
\text { dent }\end{array}$ & $\begin{array}{l}\text { Tot } \\
\text { al }\end{array}$ \\
\hline & $\mathrm{R} 1$ & 1 & 3 & 4 & 7 & 5 & 6 & 2 & 8 & \\
\hline & $\begin{array}{l}\text { Recruitm } \\
\text { ent Policy }\end{array}$ & 22 & 24 & 35 & 19 & 16 & 14 & 11 & 9 & \\
\hline & R2 & 4 & 3 & 1 & 2 & 7 & 5 & 8 & 6 & \\
\hline & $\begin{array}{l}\text { Anti-Harassment } \\
\text { and } \\
\text { Non- } \\
\text { Discrimination } \\
\text { Policy }\end{array}$ & 11 & 18 & 26 & 39 & 20 & 15 & 12 & 9 & \\
\hline & R3 & 6 & 4 & 3 & 1 & 8 & 5 & 7 & 2 & \\
\hline & $\begin{array}{ll}\text { Rewards } & \& \\
\text { Recognition } & \\
\end{array}$ & 29 & 25 & 19 & 13 & 16 & 12 & 19 & 17 & \\
\hline & $\mathrm{R} 4$ & 8 & 2 & 4 & 5 & 3 & 1 & 7 & 6 & \\
\hline & $\begin{array}{l}\text { Career } \\
\text { Planning }\end{array}$ & 25 & 23 & 15 & 17 & 28 & 14 & 13 & 15 & \\
\hline & R5 & 5 & 8 & 2 & 1 & 6 & 3 & 7 & 4 & \\
\hline & $\begin{array}{l}\text { Leave and Time- } \\
\text { Off } \quad \text { Benefits } \\
\text { Policy }\end{array}$ & 12 & 20 & 17 & 23 & 25 & 27 & 19 & 7 & \\
\hline & R6 & 7 & 4 & 8 & 5 & 3 & 2 & 6 & 1 & \\
\hline & $\begin{array}{l}\text { Compensation \& } \\
\text { Benefits }\end{array}$ & 19 & 24 & 21 & 15 & 29 & 31 & 7 & 4 & \\
\hline & R7 & 3 & 8 & 6 & 7 & 5 & 2 & 1 & 4 & \\
\hline & $\begin{array}{l}\text { Timekeeping and } \\
\text { Pay Policy }\end{array}$ & 26 & 14 & 13 & 21 & 22 & 27 & 8 & 19 & \\
\hline & R8 & 2 & 3 & 8 & 7 & 5 & 4 & 1 & 6 & \\
\hline & $\begin{array}{l}\text { Employee } \\
\text { Conduct, } \\
\text { Attendance \& } \\
\text { Punctuality } \\
\text { Policy } \\
\end{array}$ & 15 & 18 & 23 & 9 & 27 & 29 & 13 & 16 & \\
\hline & Total & 150 & 150 & 150 & 150 & $\mathbf{0}$ & 150 & 150 & 150 & \\
\hline & & Rank 1 & Rank 2 & Rank 3 & Rank 4 & $\begin{array}{l}\text { Rank } \\
5\end{array}$ & Rank 6 & Rank 7 & Rank 8 & \\
\hline \multirow[t]{8}{*}{ S.No } & & $\begin{array}{l}\text { No. of } \\
\text { Respond } \\
\text { ent }\end{array}$ & $\begin{array}{l}\text { No. of } \\
\text { Respond } \\
\text { ent }\end{array}$ & $\begin{array}{l}\text { No. of } \\
\text { Respond } \\
\text { ent }\end{array}$ & $\begin{array}{l}\text { No. of } \\
\text { Respon } \\
\text { dent }\end{array}$ & $\begin{array}{l}\text { No. of } \\
\text { Respon } \\
\text { dent }\end{array}$ & $\begin{array}{l}\text { No. of } \\
\text { Respon } \\
\text { dent }\end{array}$ & $\begin{array}{l}\text { No. of } \\
\text { Respon } \\
\text { dent }\end{array}$ & $\begin{array}{l}\text { No. of } \\
\text { Respon } \\
\text { dent }\end{array}$ & $\begin{array}{l}\text { Tot } \\
\text { al }\end{array}$ \\
\hline & R1 & 1 & 3 & 4 & 7 & 5 & 6 & 2 & 8 & \\
\hline & $\begin{array}{l}\text { Recruitm } \\
\text { ent Policy }\end{array}$ & 22 & 24 & 35 & 19 & 16 & 14 & 11 & 9 & \\
\hline & R2 & 4 & 3 & 1 & 2 & 7 & 5 & 8 & 6 & \\
\hline & $\begin{array}{l}\text { Anti-Harassment } \\
\text { and } \\
\text { Non- } \\
\text { Discrimination } \\
\text { Policy }\end{array}$ & 11 & 18 & 26 & 39 & 20 & 15 & 12 & 9 & \\
\hline & R3 & 6 & 4 & 3 & 1 & 8 & 5 & 7 & 2 & \\
\hline & $\begin{array}{ll}\text { Rewards } & \& \\
\text { Recognition } & \\
\end{array}$ & 29 & 25 & 19 & 13 & 16 & 12 & 19 & 17 & \\
\hline & $\mathrm{R} 4$ & 8 & 2 & 4 & 5 & 3 & 1 & 7 & 6 & \\
\hline
\end{tabular}




\begin{tabular}{|c|c|c|c|c|c|c|c|c|}
\hline $\begin{array}{l}\text { Career } \\
\text { Planning }\end{array}$ & 25 & 23 & 15 & 17 & 28 & 14 & 13 & 15 \\
\hline R5 & 5 & 8 & 2 & 1 & 6 & 3 & 7 & 4 \\
\hline $\begin{array}{l}\text { Leave and Time- } \\
\text { Off } \quad \text { Benefits } \\
\text { Policy }\end{array}$ & 12 & 20 & 17 & 23 & 25 & 27 & 19 & 7 \\
\hline R6 & 7 & 4 & 8 & 5 & 3 & 2 & 6 & 1 \\
\hline $\begin{array}{l}\text { Compensation \& } \\
\text { Benefits }\end{array}$ & 19 & 24 & 21 & 15 & 29 & 31 & 7 & 4 \\
\hline R7 & 3 & 8 & 6 & 7 & 5 & 2 & 1 & 4 \\
\hline \begin{tabular}{|l} 
Timekeeping and \\
Pay Policy
\end{tabular} & 26 & 14 & 13 & 21 & 22 & 27 & 8 & 19 \\
\hline R8 & 2 & 3 & 8 & 7 & 5 & 4 & 1 & 6 \\
\hline \begin{tabular}{|l|} 
Employee \\
Conduct, \\
Attendance \& \\
Punctuality \\
Policy \\
\end{tabular} & 15 & 18 & 23 & 9 & 27 & 29 & 13 & 16 \\
\hline Total & 150 & 150 & 150 & 150 & $\mathbf{0}$ & 150 & 150 & 150 \\
\hline
\end{tabular}

$$
\begin{aligned}
\mathrm{r}_{\mathrm{p}} & =1-6 \sum \mathrm{D}^{2} / \mathrm{n}\left(\mathrm{n}^{2}-1\right) \\
& =1-6 * 148 / 8(68-1) \\
& =-0.76190
\end{aligned}
$$

R5= Rank given to Leave and Time-Off Benefits

Policy

R8=Rank given to Employee Conduct, Attendance

\& Punctuality Policy.

Decision for $\mathrm{n}=8$

Conclusion: There is a correlation between the factors of Enlistment and Employee Conduct, Attendance \& Punctuality Policy. Hence the recruitment and selection has an impact over performance management.

\section{Discovery of the Research:}

$78 \%$ of the majority of the HR professionals at BPO are not aware of the HR policies and only $22 \%$ people are do aware of the policies.

A supreme portion of $33 \%$ of the HR's sense that it affects the decision making on the performance evaluation of employees and $26 \%$ HR domain up gradations. A little amount of $24 \%$ and $17 \%$ of them feel its impacts related to organization policies knowledge and recruitment of the apt personnel.

$28 \%$ and $19 \%$ of the respondents feel that Recruit Policy and Reward \& Recognition are the best practices in the company. $14 \%$ and $12 \%$ of the respondents feel that $\mathrm{r}_{\mathrm{p}}=$ Spearman's Rank Correlation

$\mathrm{n}=$ No. of Observations, $\mathrm{d}=$ deviations 
Customer Expectations and Scarcity of talent.

The age of HR professionals and their level of awareness varies with respect to HR Policies
Hence, Leave and Time-Off Benefits Policy has a profound influence on Employee Conduct, Attendance and Punctuality Policy.

\section{MARKET SIZE OF THE BPO SERVICES FROM THE PAST 10 YEARS TO THE} PREDICTION OF THE NEXT 5 YEARS:

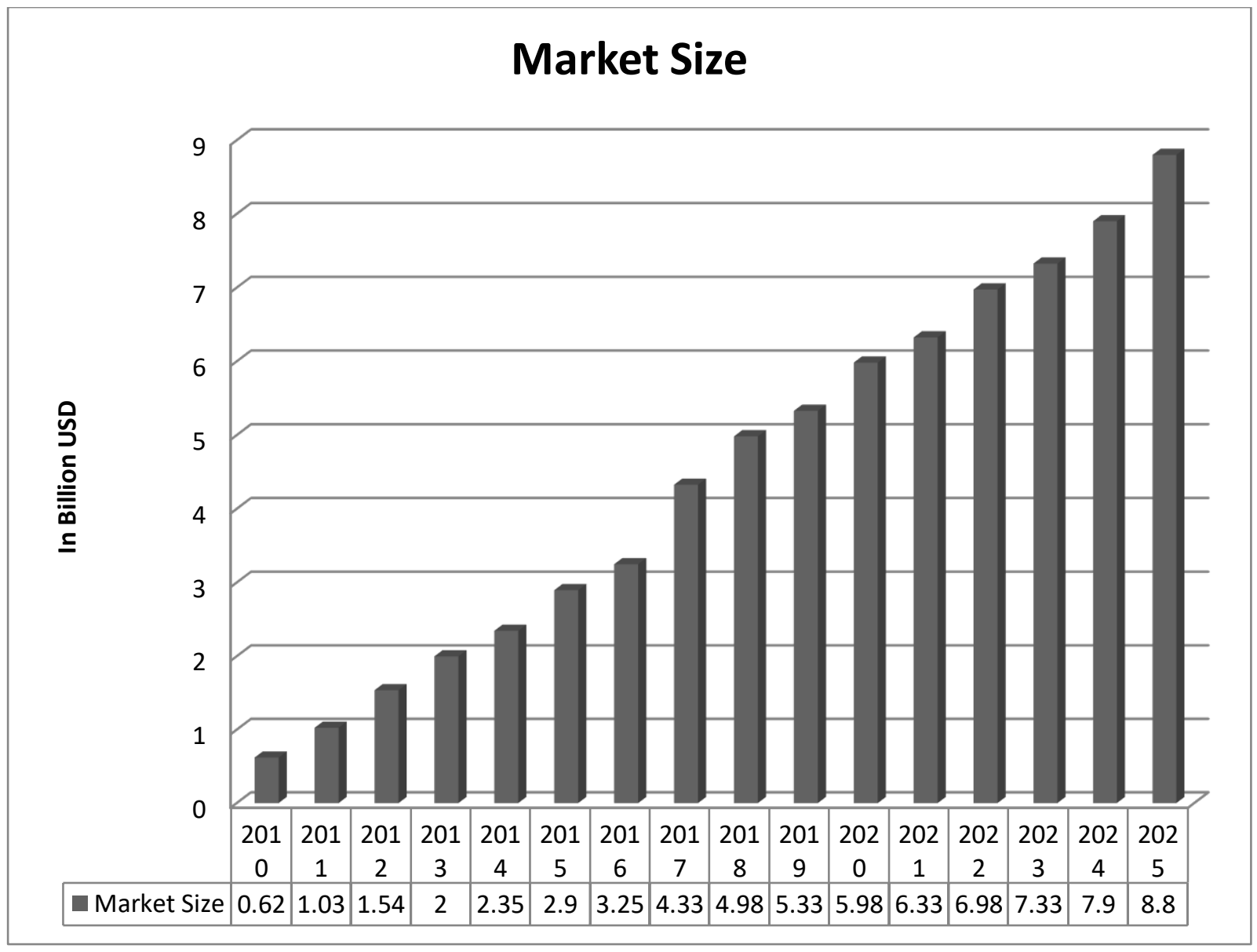

\section{Research Conclusion:}

Growth of BPO sector in India has been truly impressive in recent years, but things can get even better, according to market analysts. Growth of BPO Sector in India during most of the beginning part of 2007 was showing a adequate trend of magnification which is registered at $14 \%$. 5 years ago, the maturation in this sector was quite shallow due to less contracts but the situation has worsened now. However, the growth of the BPO sectors are expected to ameliorate. The HR manager takes part in a huge role in this. The walk-on part of the factory managers and the immediate superintends are proportionately important. The rudimentary responsibility extensively would lie on the top-shelf managers, for it is they who are in control of 
supervising the policy implementation; HR professionals can give counsel advice or guidance, but it is the front-line managers who are present on the spot, and have to make decisions about the people. So its their responsibility to look over the fact that professionals working under the BPO's are considered as investments and have knowledge of every advantage they are entitled to.

\section{Reference:}

[1]. K Ramachandran and Sudhir Voleti, Business Process Outsourcing (BPO): Emerging Scenario and Strategic Options for IT-enabled Services-

https://journals.sagepub.com/doi/pdf/10.1177/0256090920040105

[2]. Mark A. Huselid, Academy of Management Journal, Vol. 38, No. 3, pp. 635-672, 1995, The Impact of Human Resource Management Practices on Turnover, Productivity, and Corporate Financial Performance.https://papers.ssrn.com/sol3/papers.cfm?abstract_id=1803666

[3]. Neelie Verlinden, Academy to Innovate HR, 9 Digital HR Case Studies with Business Impact https://www.aihr.com/blog/digital-hr-case-studies-2/

[4]. P.Elantheraiyan, Mr.S.Anand, Assistant Professor, School of Management Veltech University Avadi Chennai-62 International Journal of Engineering \& Technology -

\section{https://www.sciencepubco.com/index.php/IJET}

\section{[5]. Sumitro Mukherjee-}

https://www.researchgate.net/publication/228138997_Business_Process_Outsourcing_and_India 